\title{
Pembuatan Kemasan Produk Ikan Asap di Desa Suradadi sebagai Strategi Promosi Produk
}

\author{
Ike Desi Florina ${ }^{1}$, Sri Mulyani² ${ }^{2}$ Itsna Hidayatul Khusna ${ }^{3}$ \\ 1, 2 Universitas Pancasakti Tegal, ${ }^{3}$ Universitas Jenderal Soedirman
}

\begin{abstract}
Article History ABSTRACT
Received 06.09.2019

Received in revised form

29.11.2019

Accepted 04.12.2019

Available online 16.12.2019

MAKING SMOKED FISH PRODUCT PACKAGING IN SURADADI VILLAGE AS A PRODUCT PROMOTION STRATEGY. Promotion is the common problem for micro enterpreneur/start up to increase product selling. This problem has been problem for smoked fish producer in Suradadi Village, Tegal Regency. To resolve these problems, we as service society team made an action along with smoked fish producer as partner. In this activities we used several methodes that is socialization, building renovation, packaging, and promoting. The socialization was consist of promotion strategy socialization, and training in the use of social media. Renovation is done by replacing defective building, organizing and cleaning the place which located for place of business. Next is to make product packaging, so that the product looks more attractive to buy. Promotion activities was utilize social media for product promotion, and install signpost near roadway to point business place. The results achieved from this partnership activity are an increase in buyer knowledge of smoked fish products, and an increase in the number of buyers with the promotion of social media and the installation of signposts.
\end{abstract}

KEYWORDS: Packaging, Promotion, Smoked Fish.

\section{PENDAHULUAN}

Permasalahan yang dialami oleh pelaku usaha kecil menengah kebanyakan adalah promosi produk. Hal yang sama dialami oleh perajin ikan asap di Desa Suradadi, Kabupaten Tegal. Kesulitan mempromosikan produk kepada pembeli membuat usaha ini sulit untuk berkembang. Perlu dikenal secara luas bahwa Desa Suradadi yang terletak di Kabupaten Tegal berada di pesisir pantai utara Jawa Tengah yang mengandalkan perekonomian dari hasil laut. Salah satu perajin ikan asap di Desa Suradadi adalah Ilbu Rasminah. Dia sudah menjalankan usahanya selama tiga tahun. Dalam pengakuannya, usaha ikan asapnya tersebut bisa menghabiskan ikan sebanyak $75 \mathrm{~kg}$. Menurutnya,

${ }^{1}$ Corresponding author: Universitas Pancasakti Tegal, Jl. Halmahera, KM.1 Mintaragen, Tegal Timur, Kota Tegal, Indonesia. Email ike.florina@gmail.com 
usahanya tersebut bisa menghabiskan lebih banyak lagi tetapi tidak ada keberanian untuk menambah jumlah ikan, alasannya adalah takut produknya tidak laku terjual. Karena selama ini, produk ikan asapnya tersebut dijual kepada pembeli pertama yang nantinya oleh pembeli ini akan dijual lagi ke konsumen terakhir. Dan pembeli pertama selalu membeli dengan jumlah yang terbatas. Atas permasalahan tersebut, kami melakukan kegiatan pemberdayaan kepada masyarakat (PKM), yang tujuannya adalah untuk membantu memecahkan permasalahan yang dihadapi oleh Ibu Rasminah.

Selama tiga tahun usahanya berdiri, Ilbu Rasminah mengaku tidak pernah kesulitan dalam pasokan ikan. Hal ini dikarenakan tempat usaha Ibu Rasminah berada satu lokasi dengan tempat pelelangan ikan Desa Suradadi. Bahan ikan yang mudah didapat membuat usaha Ibu Rasminah bisa terus menerus memproduksi ikan asap. Usahanya ini telah berhasil meningkatkan ekonomi keluarga dan membiayai anaknya sekolah. Keinginan Ibu Rasminah adalah produknya bisa dikenal oleh masyarakat luas, sehingga banyak yang tertarik untuk membeli produknya, dengan demikian dia bisa menambah jumlah produksi.

Melihat dari permasalahan Ibu Rasminah tersebut, tim PKM memberikan solusi yaitu promosi produk untuk memperkenalkan produk ikan asap kepada masyarakat luas. Promosi adalah sebuah kekuatan pemasaran atas sebuah produk karena itu promosi produk harus direncanakan dengan matang. Menurut Kotler (2009), Promosi adalah bagian dan proses strategi pemasaran sebagai cara untuk berkomunikasi dengan pasar, dengan menggunakan komposisi bauran pemasaran (promotional mix). Bauran pemasaran adalah strategi gabungan empat elemen kunci pemasaran: produk, harga, distribusi, dan promosi, yang digunakan untuk memasarkan produk. Eddy Soeryanto Soegoto (2009, p. 182) menyatakan promosi merupakan aspek terpenting karena promosi adalah hal yang terakhir agar tujuan dari perusaahan tercapai setelah menetapkan tiga bauran pemasaran lainnya. Hal yang termasuk kedalam promosi yaitu promosi penjualan, iklan, hubungan masyarakat dan publikasi, pemasaran langsung dan penjualan personal. Untuk mewujudkan hal tersebut, perlu mempersiapkan produk dengan sebaik mungkin, salah satu yang dilakukan adalah dengan membuat kemasan produk. Pembuatan kemasan produk akan meningkatkan nilai jual produk, karena hal pertama yang akan dilihat oleh pembeli adalah kemasannya.

Kegiatan PKM ini difokuskan meningkatkan kualitas produk dengan jalan pembuatan kemasan sebagai sarana promosi produk. Kemasan suatu identitas yang lebih efektif, dengan sendirinya mencegah pertukaran oleh produk pesaing, karena kemasan merupakan satu-satunya cara perusahaan membedakan produknya (Mukhtar \& Nurif, 2015).Tujuan akhirnya adalah produk menarik di mata konsumen dan bisa dikenal luas oleh masyarakat, sehingga banyak yang tertarik untuk membeli produk tersebut dengan demikian bisa meningkatkan jumlah produksi dan akan meningkatkan pendapatan. Efek lain yang bisa diperoleh saat produk sudah dikenal luas adalah produk bisa menjadi oleholeh khas dari daerah tersebut sebagai salah satu produk kearifan lokal.

Kegiatan PKM ini juga menjadi gerbang yang bagus untuk menjalin hubungan antara perguruang tinggi dengan masyarakat. Ini merupakan tugas Tridharma perguruang tinggi yang diamanatkan oleh undang-undang. Kegiatan ini terlaksana atas dukungan penuh dari Kementerian Riset, Teknologi, dan Pendidikan Tinggi dan Universitas Pancasakti Tegal. 


\section{METODE PELAKSANAAN}

Fokus dari kegiatan PKM adalah membuat kemasan produk, seperti hasil pengabdian pada masyarakat yang telah dilaksanakan oleh Basri (2018) yang berjudul "Peningkatan Kualitas Produk pada Usaha Pembuatan Tortila Jagug dan Kerupuk Gadung dengan Pendekatan Evaluasi Merek dan Kemasan" menyebutkan bahwa kemasan dan label produk dengan pendekatan desain grafis sesuai standar kemasan akan berpengaruh terhadap minat responden yang juga selaku konsumen produk. Namun sebelum membuat kemasan produk ada beberapa kegiatan pendukung yang dilakukan terlebih dahulu. Sebelum ke kemasan produk perlu memerhatikan kualitas produk, dan meningkatkan kesadaran dan pemahaman mitra tentang pentingnya promosi produk. Untuk itu metode yang dilakukan dalam kegiatan PKM ini ada empat tahap, yaitu sosialisasi, renovasi tempat usaha, pengemasan (packaging), dan promosi.

\section{Sosialisasi}

Sosialisasi dilakukan dengan pendekatan personal secara persuasif, hal ini dilakukan untuk menyiptakan kedekatan antara pengabdi dengan mitra. Hal-hal yang dilakukan dalam kegiatan sosialisasi adalah: 1) Memberikan pemahaman tentang pentingnya penataan tempat usaha; 2) Meliterasi pentingnya pembuatan kemasan sebagai strategi promosi; dan 3) Memberikan kesadaran akan pentingnya menggunakan teknologi informasi dan komunikasi dalam penjualan produk.

\section{Renovasi Tempat Usaha}

Sebelum mengemas produk, hal yang perlu diperhatikan oleh produsen adalah menjaga kualitas produk, langkah yang bisa dilakukan untuk meningkatkan kualitas produk adalah: Pertama, menata tempat usaha dengan jalan: 1) Membersihkan lokasi; 2) Memasang terpal sebagai alas lantai;3) Memperbaiki atap yang terbuat dari terpal; dan 4) Memperbanyak baskom/ember untuk mencuci ikan.

Kedua, memperbaiki dan memperbanyak alat produksi dengan cara: 1) Menambah alat pengasapan yaitu alat panggang dan baskom untuk pengasapan; 2) Memperbaiki dan menambah alat jemur ikan yang telah dibersihkan; dan 3) Memperbanyak pisau potong dan talenan berdiameter lebar.

Ketiga, menginisiasi izin usaha melalui dinas koperasi dan dinas kesehatan setempat untuk memberikan jaminan bahwa produk tersebut aman untuk dikonsumsi dan berkualitas.

\section{Packaging}

Kemasan merupakan salah satu solusi untuk menarik perhatian konsumen karena berhadapan langsung dengan konsumen (Cenadi, 2000). Pengemasan produk dilakukan dengan cara: 1) Memberi vacuum sealer dan vacuum bag; 2) Melatih penggunaan vacuum sealer; 3) Membuat penamaan produk yang menarik namun tetap sesuai lokalitas; dan 4) Mendesain kertas label yang menarik (Christy, 2014). Pelatihan mengenai Desain Kemasan Produk, guna memberikan keterampilan bagi masyarakat khusus nya UMKM juga pernah dilakukan dalam bentuk pengabdian masyarakat oleh Rofieq, Poerwanto, dan Budiyanto (2017) dari Universitas Merdeka Malang. 


\section{Promosi}

Promosi dilakukan dengan langkah-langkah: 1) Memberi telepon seluler dengan software android atau smartphone; 2) Melatih penggunaan smartphone; 3) Membuat akun media sosial; 4) Memasang papan plang/billboard sebagai penunjuk arah lokasi usaha; dan 5) Menginisiasi kerjasama dengan toko pusat oleh-oleh untuk memasarkan produk.

\section{HASIL DAN PEMBAHASAN}

Kegiatan PKM dilaksanakan dari $(b$, terselenggara atas kerja sama dari tim PKM Universitas Pancasakti Tegal dengan Ristekdikti. Kegiatan yang dilakukan adalah:

\section{Sosialisasi}

Sosialisasi dilakukan dengan memberikan pemahaman tentang pentingnya promosi produk yang dilakukan dengan membuat kemasan. Memberikan edukasi mengenai promosi dan penggunaan telepon selular sebagai alat promosi. Kegiatan ini dilaksanakan di lokasi mitra dengan menjelaskan pengetahuan tentang promosi produk dan penggunaan media sosial sebagai sarana promosi. Sosialisasi dilakukan dengan pendekatan persuasif agar tidak ada jarak antara pengabdi dengan mitra.

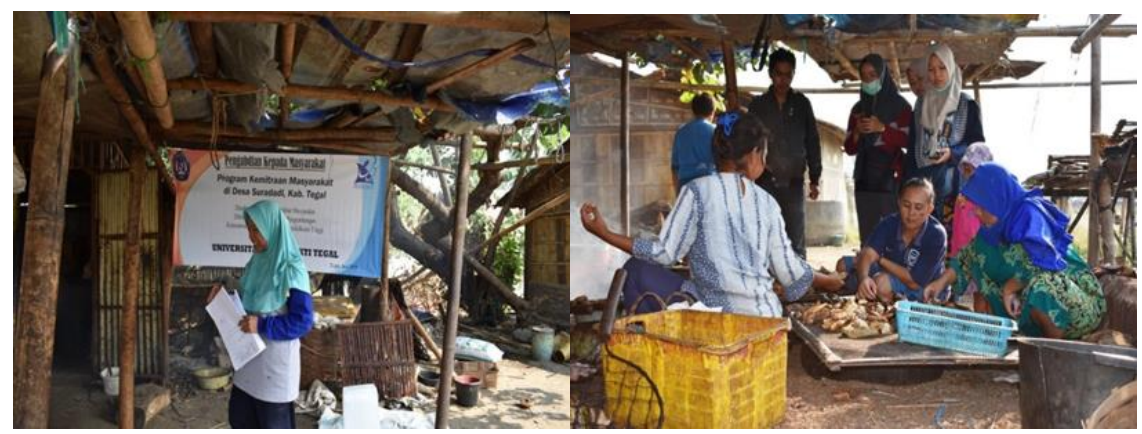

Gambar 1. Kegiatan Sosialisasi

Tujuan yang dicapai dari kegiatan ini adalah meningkat kesadaran mitra akan pentingnya meningkatkan kualitas produk dalam upaya promosi produk. Mitra mengubah pandangan tentang pentingnya menguasai strategi promosi dalam menjual produk. Mitra mau mengikuti semua kegiatan yang diprogramkan oleh tim PKM dengan sukarela.

\section{Renovasi Tempat Usaha}

Sebelum produk dikemas yang perlu diperhatikan adalah meningkatkan kualitas produk. Kegiatan ini dilakukan dengan menata tempat usaha, dan memperbaiki dan memperbanyak alat produksi.

\section{Penataan tempat usaha}

Kegiatan dilakukan untuk memperbaiki fisik bangunan yang sudah tidak layak, dan untuk menjadikan tempat usaha lebih bersih. 


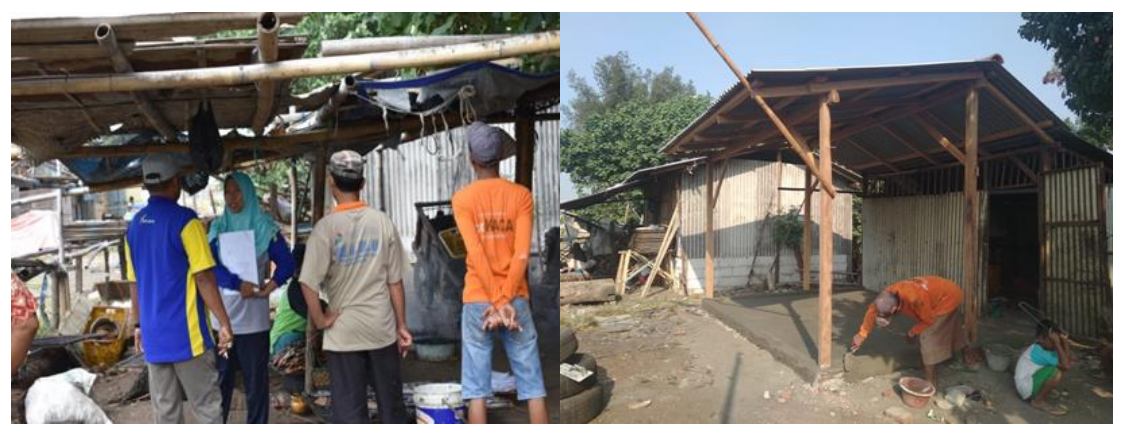

Gambar 2. Proses Renovasi Tempat Usaha

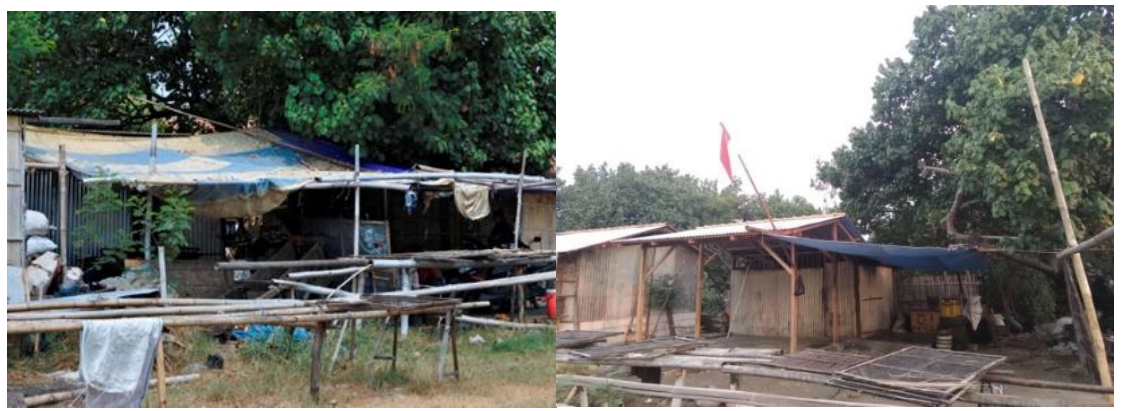

Gambar 3. Sebelum Renovasi (kiri) dan Sesudah Renovasi (kanan)

Penataan tempat ini dilakukan dengan tujuan agar mendapatkan kesan positif dari pembeli yang langsung membeli ikan asap di lokasi usaha. Produk yang dihasilkan bersih dan higienis, sehingga kualitas produk meningkat. Kebersihan tempat usaha juga akan mempermudah dalam pengurusan izin usaha.

\section{Perbaikan alat produksi}

Saat melakukan survei, tim menemukan bahwa alat yang digunakan untuk produksi sudah banyak yang rusak dan tidak layak pakai. Agar kegiatan produksi kedepan berjalan dengan baik, maka pada kegiatan pengabdian ini juga dilakukan perbaikan alat produksi, penggantian, serta memperbanyak alat.

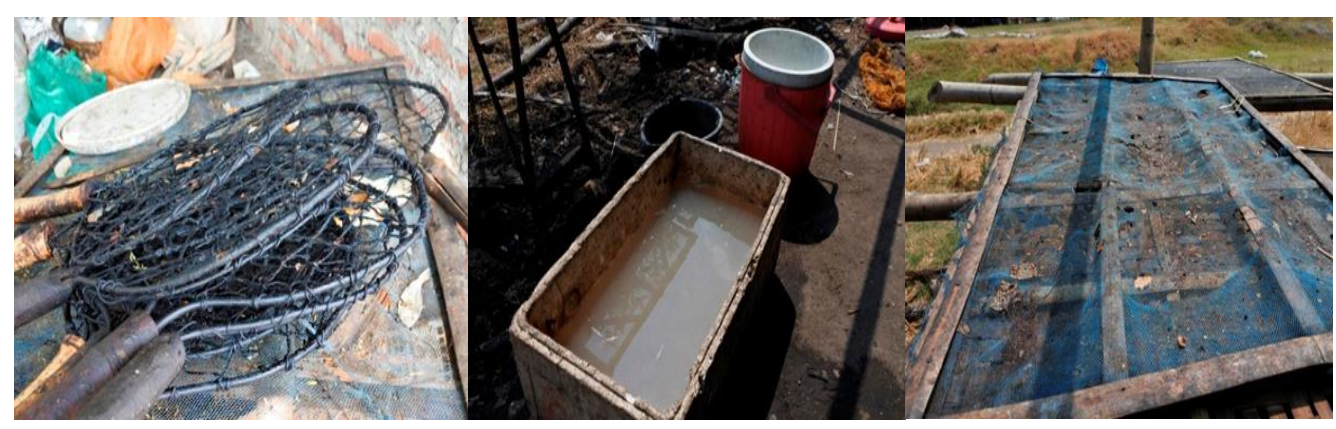

Gambar 4. Alat Produksi Saat Survei Awal 


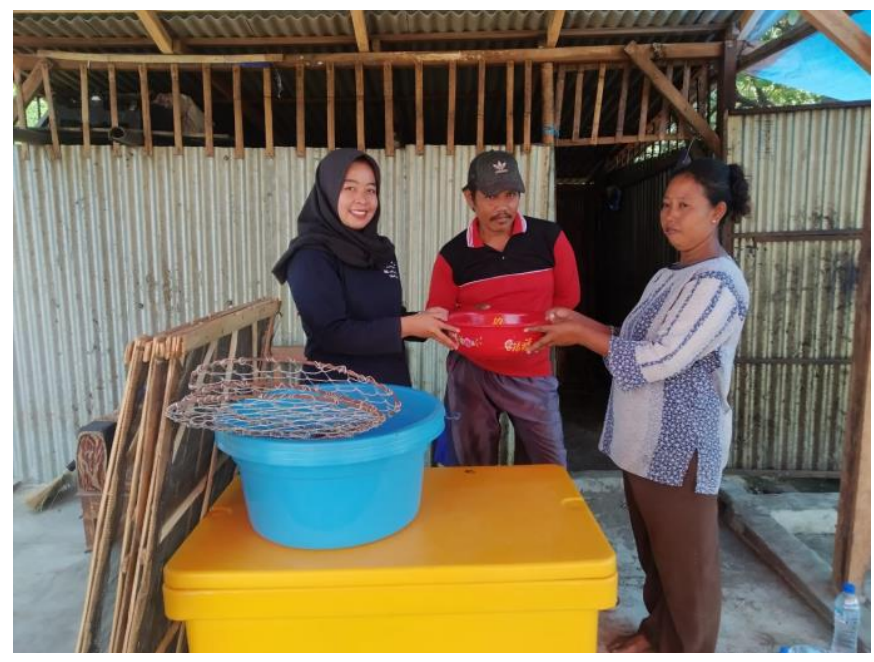

Gambar 5. Serah Terima Alat Produksi yang Baru

\section{Packaging}

Kegiatan pengemasan produk ini ditujukan untuk melindungi bahan pangan segar maupun bahan pangan olahan dari penyebab kerusakan, baik fisik, kimia, maupun mekanis (Herudiyanto, 2008). Yakni dengan terlebih dahulu menyediakan alat pengemas, yaitu vacuum sealer beserta vacuum bag (plastik). Membuat desain untuk plastik kemasan, dan mengajarkan cara menggunakan alat vacuum tersebut sampai produk siap dipasarkan. Bagi Klimchuk dkk (2006) konsep desain logo dan nama merek, daya tarik visual dan citra merek dapat membawa pengaruh terhadap daya beli. Penamaan yang khas dan lokal menambah daya ingat kuat bagi masyarakat sekitar dan masyarakat umum.

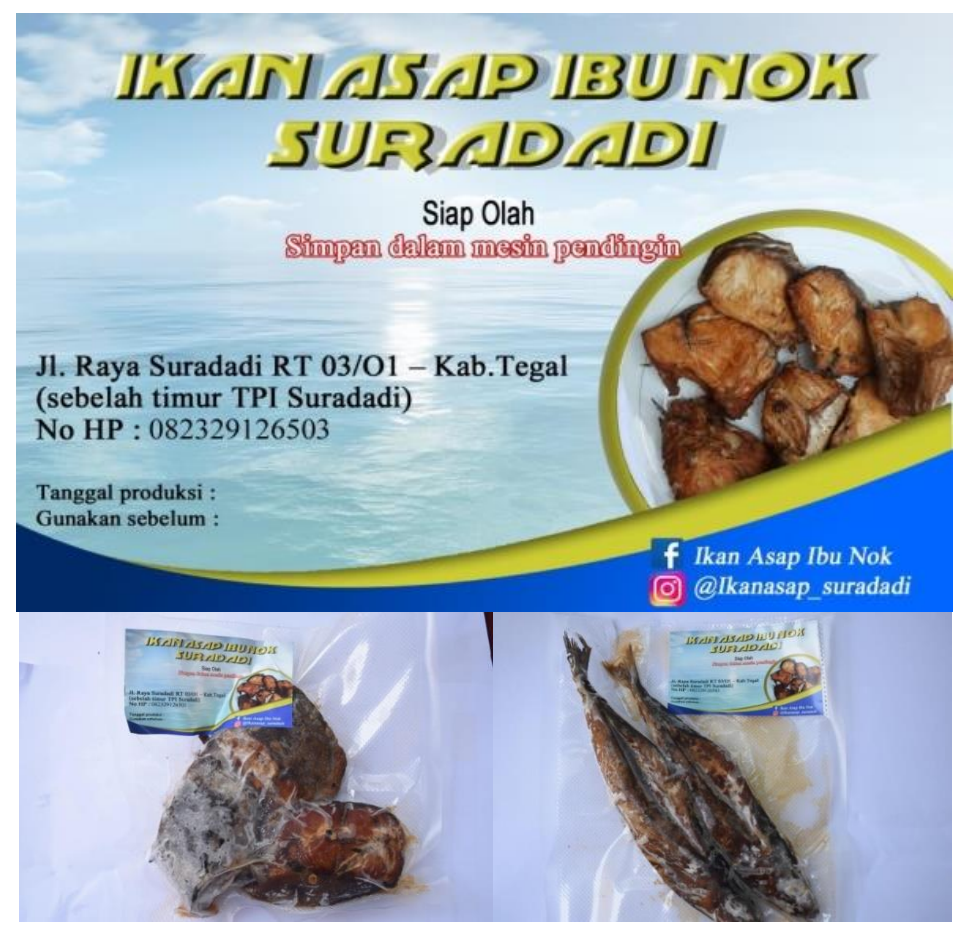

Gambar 6. Desain dan Produk Ikan Asap Ibu Nok Suradadi 


\section{Promosi}

Kegiatan ini diawali dengan pemberian pemahaman mengenai promosi dan pentingnya promosi. Untuk mendukung kegiatan ini, dilakukan pelatihan penggunaan telepon selular dan pembuatan akun media sosial untuk memasarkan produk. Saat ini media sosial digunakan sebagai alat pemasaran interaktif, pelayanan, membangun komunikasi dengan pelanggan dan calon pelanggan, serta ebagi alat untuk menjual dan membeli produk secara online (Morissan, 2007). Dalam kegiatan ini selain pelatihan pengunaan media sosial, promosi dilakukan dengan memasang plang arah petunjuk lokasi produksi di pinggir jalan agar orang yang sedang lewat di jalan raya tertarik untuk mengunjungi.

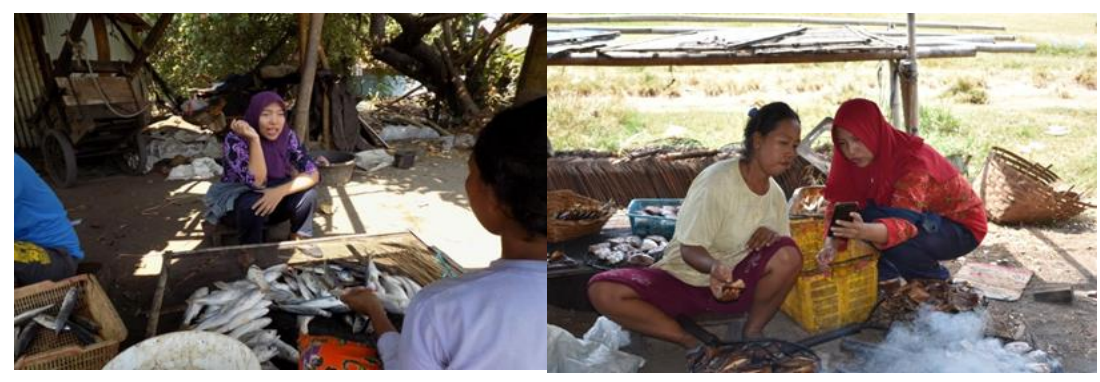

Gambar 7. Pelatihan Penggunaan Smartphone

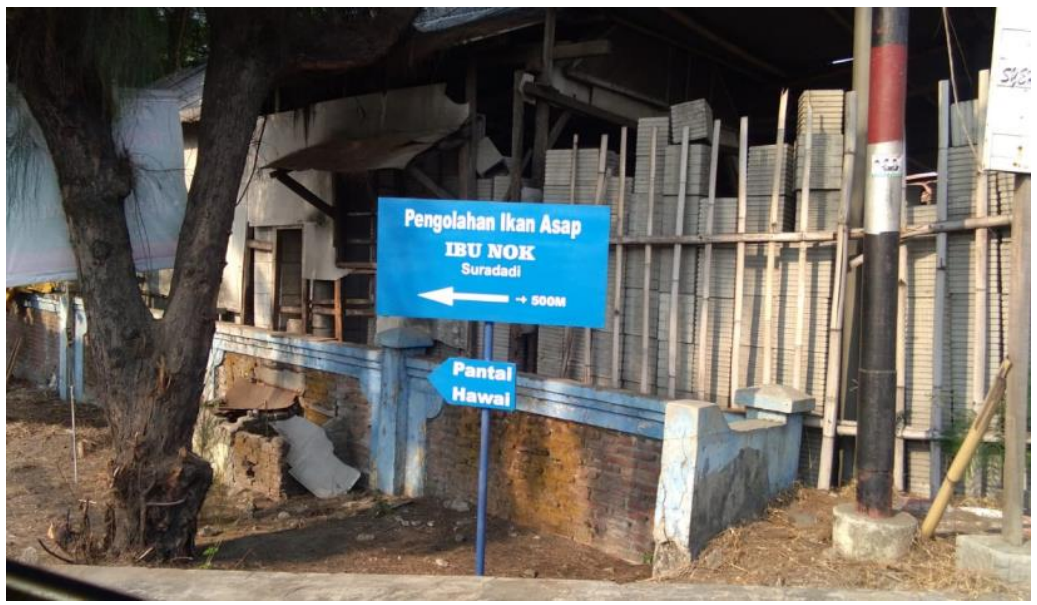

Gambar 8. Plang Petunjuk Arah Menuju Tempat Usaha Ikan Asap

Saat ini, mitra sudah mulai menggunakan media sosial sebagai sarana promosi produknya, agar produknya dikenal jauh oleh masyarakat. Baik masyarakat sekitar maupun pengendara yang kebetulan melintas di jalur pantura. Media sosial yang digunakan adalah Instagram, media sosial ini dipilih karena pengguna media sosial ini di Indonesia sangatlah banyak, sehingga media ini sangat tepat untuk digunakan sebagai sarana promosi produk. 


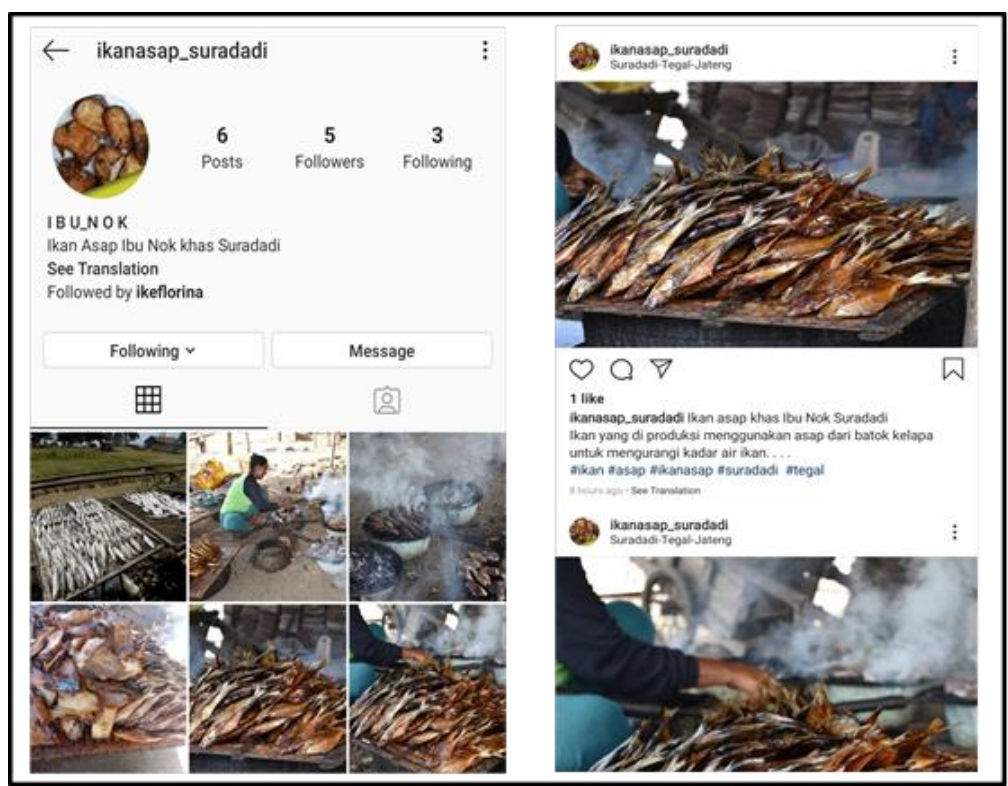

Gambar 9. Akun Instagram Mitra PKM

\section{SIMPULAN}

Kegiatan pengabdian kepada masyarakat ini utamanya adalah untuk memberdayakan masyarakat. Dalam kegiatan ini tujuan yang dicapai dalah peningkatan kualitas produk agar produk mempunyai nilai ekonomis yang lebih. Untuk mendapatkan produk yang berkualitas, serangkaian kegiatan telah dilakukan oleh pelaksana. Mulai dari sosialisasi, penataan tempat usaha, pelatihan packaging, dan pelatihan penggunaan smartphone. Dalam proses kegiatannya mitra menunjukkan semangat luar biasa dalam mengikuti semua tahapan yang sudah direncakan oleh tim pengabdian sebelumnya. Hal ini bisa dirasakan dengan penerimaan mitra terhadap tim dan tidak adanya jarak antara mitra dengan tim pelaksana. Ikatan ini bisa terjalin karena selama kegiatan berlangsung tim pengabdian menggunakan pendekatan personal dan persuasif. Mendengarkan masukan dari mitra yang kemudian diserap dan dipertimbangkan untuk dilaksanakan.

Patut disadari bahwa dalam kegiatan memberdayakan masyarakat, kita seharusnya menyesuaikan kebutuhan mitra, jadi mitra diajarkan untuk memahami masalah mereka sehingga mereka mau berupaya untuk memecahkan solusi tersebut. Selain itu mitra juga tidak merasa dimanfaatkan, karena sering terjadi pada mitra namanya hanya dimanfaatkan untuk mendapatkan dana bantuan tetapi bantuannya tidak pernah sampai kepada mitra. Hal seperti ini yang jarang dilakukan pada program pemberdayaan, karena program yang muncul sering dimulai dari top-down, bukan bottom-up. Kenyataan ini yang biasanya membuat program pemberdayaan gagal atau tidak berlanjut.

Untuk mendukung pelaku usaha kecil dan menengah, pemerintah daerah perlu terus menerus melakukan monitoring dan evaluasi. Lemahnya pengawasan mengakibatkan program dari pusat terhenti di elit desa. Pemerintah daerah harus aktif dalam memberikan motivasi dan pelatihan-pelatihan untuk meningkatkan pengetahuan dan keterampilan pelaku usaha kecil. Dengan demikian, industri kecil dan menengah akan bergeliat yang nantinya dapat meningkatkan pendapatan daerah. 


\section{REFERENCES}

Basri, B., \& Qashlim, A. (2018). Pemberdayaan UMKM Desa Kunyi melalui potensi umbi gadung dengan pendekatan promosi berbasis teknologi. CARADDE: Jurnal Pengabdian Kepada Masyarakat, 1(1), 44-49. https://doi.org/10.31960/caradde.v1i1.6.

Cenadi, C. S. (2004). Peranan desain kemasan dalam dunia pemasaran. Nirmana, 2(2), 92103.

Christy, P. (2014). Pengaruh desain kemasan (packaging) pada impulsive buying. Yogyakarta: Universitas Atma Jaya.

Herudiyanto, M. S. (2008). Teknologi pengemasan pangan. Bandung: Widya Padjadjaran.

Klimchuk, M. R., \& Krasovec, S. A. (2006). Desain kemasan: Perencanaan merek produk yang berhasil mulai dari konsep sampai penjualan. Jakarta: Erlangga.

Kotler, P., \& Keller, K. L. (2009). Manajemen pemasaran. Jakarta: Erlangga.

Morissan. (2007). Periklanan komunikasi pemasaran terpadu. Tangerang: Ramdina Perkasa.

Mukhtar, S., \& Nurif, M. (2015). Peranan packaging dalam meningkatkan hasil produksi terhadap konsumen. Jurnal Sosial Humaniora, 8(2), 181-191.

Rofieq, M., Poerwanto, A., \& Budiyanto, H. (2017). Pelatihan desain kemasan produk untuk UMKM kerajinan, kuliner dan Posdaya. Jurnal Pengabdian Kepada Masyarakat, 2(2), 1-6.

Soegoto, Eddy Soeryanto. 2009. Entrepreneurship: Menjadi pebisnis ulung. Jakarta: Elex Media Komputindo. 